УДК 338.3

JEL F63, O47, F02

Трофименко О. О.

канд. економ. наук доцент, ORCID: 0000-0002-2339-0377

Національний технічний університет України «Київський політехнічний інститут ім. Ігоря Сікорського»

Дорошкевич Д. В. доктор економ. наук, доцент, ORCID: 0000-0003-0421-0630

Національний технічний університет Украӥни «Київський політехнічний інститут ім. Ігоря Сікорського»

Джадан I. М. ORCID: 0000-0003-3887-4312 Наиіональний інститут стратегічних досліджень

\title{
МІСЦЕ УКРАЇНИ У КООРДИНАТАХ ЦІЛЕЙ СТАЛОГО РОЗВИТКУ (НА ПРИКЛАДІ ЦІЕЙ 8, 9, 12, 17)
}

\author{
UKRAINE'S PLACE IN THE COORDINATES OF THE SUSTAINABLE \\ DEVELOPMENT GOALS (ON THE EXAMPLE OF GOALS 8, 9, 12, 17)
}

У статті визначено актуальність формування економічної політики на засадах сталого розвитку. Визначено иілі сталого розвитку, які сприяють економічному зростанню та розвитку промисловості, а саме: Ціль 8 "Достойні робочі місия та економічне зростання”, Ціль 9 “Інновації й інфраструктура”, Ціль 12 “Відповідальне споживання”, Ціль 17 “Співпраия заради досягнення иілей”. Обрано країни для порівняння з Україною для визначення рівня досягнення визначених иілей. Проведено компаративний аналіз вторинних даних показників досягнення цілей сталого розвитку. Наведено результати перерахунку балів за індексом SDG за чотирма обраним чілям і проведено порівняння прогресу краӥн за кожною з чотирьох иілей окремо. Сформували перелік лідерів ТОП-10 країн за загальним показником індексу SDG 2019 р. і порівняли його з рейтингом досліджуваних краӥн за даним показником. Визначено суттєву зміну рейтингів досліджуваних 13-ти країн залежно від значень індексів SDG за окремими иілями, та визначені основні причини. Представили результати перерахунку рейтингу досліджуваних країн за чотирма иілями та проаналізували отримані зміни. У межах дослідження подали динаміку реального ВВП на душу населення $у$ досліджуваних країнах з 2009 по 2018 рр. Проаналізували рейтинг досліджуваних країн $i$ позииію України за глобальним інноваційним індексом, як одного з важливих загальних глобальних показників, який відображає досягнення за Ціллю 9 та частково Ціллю 8 сталого розвитку. Співставили результати Украӥни з досліджуваними країнами в рейтингу за індексом екологічної ефективності, який можна віднести до індикаторів за Ціллю 12 сталого розвитку. Враховуючи отримані результати надали рекомендації щодо того, досвід яких 
краӥн слід враховувати з метою формування заходів для сталого розвитку економіки в Украӥні та подальші кроки щзодо аналізу циих краӥн.

Ключові слова: сталий розвиток, економічне зростання, промисловість, глобальний інноваційний індекс

The article identifies the relevance of economic policy formation on the basis of sustainable development. Sustainable development goals that contribute to economic growth and industrial development are identified, namely: Goal 8 "Decent work and economic growth", Goal 9 "Industry, Innovation and Infrastructure", Goal 12 "Responsible consumption and Production", Goal 17 "Partneships". Countries for comparison with Ukraine to determine the level of achievement of certain goals are selected. A comparative analysis of secondary data on indicators of achieving sustainable development goals is used. The results of recalculation of points on the SDG index for the four selected goals are presented and the progress of countries for each of the four goals is compared separately. A list of leaders in the top 10 countries on the overall indicator of the SDG index in 2019 is formed and compared with the ranking of the surveyed countries on this indicator. A significant change in the ratings of the 13 countries studied depending on the values of the SDG indices for individual purposes and the main reasons are identified. The results of the recalculation of the ranking of the studied countries for four purposes are presented and analyzed. The dynamics of real GDP per capita in the studied countries from 2009 to 2018 are presented. The ranking of the studied countries and Ukraine's position on the global innovation index, as one of the important overall global indicators, which reflects the achievements of Goal 9 and partly Goal 8 sustainable development are analyzed. The results of Ukraine with the studied countries in the ranking of the environmental efficiency index, which can be attributed to the indicators of Goal 12 of sustainable development are compared. Taking into account the obtained results, recommendations on which countries' experience should be taken into account in order to form measures for sustainable economic development in Ukraine and further steps to analyze these countries are provided.

Keywords: sustainable development, economic growth, industry, global innovation index

Вступ. Сьогодні в Україні триває процес доопрацювання Стратегії розвитку промислового комплексу до 2025 р. з огляду на пріоритети нової промислової стратегії ЄС. Формування ефективної власної стратегії розвитку промислового комплексу, яка буде враховувати європейські виклики та цінності $\mathrm{CC}$, надасть можливість підвищити якість промислової продукції України та іiі конкурентоспроможність. У даному дослідженні нами виокремлено цілі серед Глобальних Цілей сталого розвитку до 2030 р., затверджених на саміті ООН з питань сталого розвитку [1], на засадах яких доцільно розвивати промисловість України. Важливо проаналізувати прогрес України відносно інших країн щодо досягнення даних цілей, що впливають на економічне зростання.

Постановка завдання. Метою дослідження $є$ порівняння показників досягнення цілей сталого розвитку в сфері економічного зростання України 3 іншими країнами, та визначення країн, на які доцільно орієнтуватися на шляху 
досягнення конкретних цілей економічного розвитку на засадах цілей сталого розвитку.

Методологія. 3 метою дослідження України та інші країни в індикаторах Цілей сталого розвитку використано компаративний аналіз вторинних даних 3 «Sustainable Development Report» [2], Глобального інноваційного індексу [3] та Індексу екологічної ефективності [4]. Для дослідження обрали чотири цілі сталого розвитку (ЦСР), які стосуються або позитивно впливають на економічне зростання та промисловий розвиток країни, а саме: Ціль 8 "Достойні робочі місця та економічне зростання", Ціль 9 "Інновації й інфраструктура", Ціль 12 “Відповідальне споживання”, Ціль 17 “Співпраця заради досягнення цілей”. Для аналізу прогресу в досягненні цілей Сталого розвитку обрано такі країни: Білорусь, Польща, Угорщина, Латвія, Литва, Естонія, Канада, Сполучене Королівство, Німеччина, Франція, Туреччина, Португалія, Італія. Так, Білорусь, Польща, Угорщина. Дані країни були обрані за такими критеріями: країнисусіди, схожі ресурсні можливості, країни, 3 якими Україна співпрацює за різними напрямами, країни з провідною економікою та високим рівнем ВВП. Так, наприклад, Туреччина є країною, що тісно співпрацює з Україною і в січні 2020 р. в Анкарі пройшов черговий раунд переговорів щодо укладення Угоди про вільну торгівлю між Україною та Турецькою Республікою. Польща є не тільки сусідом, але й багаторічним партнером України. Білорусь є сусідом i, водночас, активно займається досягненням цілей сталого розвитку. Канада, Сполучене Королівство, Німеччина, Франція є країнами з високим рівнем ВВП.

Результати дослідження. Для аналізу та співставлення досягнення цілей 8 , 9, 12,17 сталого розвитку за використовували дані звітів незалежних експертів зі сталого розвитку за 2017-2019 pp. «Sustainable Development Report» [2], відповідно до їх методології, показник по досягненню окремих цілей $\epsilon$ інтегральним з врахуванням окремих індикаторів.

Так, звіт «Sustainable Development Report» за 2019 рік характеризує прогрес країн у досягненні цілей сталого розвитку та вказує на сфери, які потребують швидшого прогресу. Кожній країні присвоюється відповідний SDG індекс, за яким можна оцінити загальний показник досягнення всіх цілей сталого розвитку по кожній країні та рейтингувати країни від більшого значення індексу до меншого. Зі 162 країн, які оцінюються у звіті в 2019 р. найбільше значення індексу SDG (1 місце у рейтингу) у Данії - 85,2, найменше значення індексу SDG у Центральноафриканській Республіці - 39,1. Україна посіла у 2019 р. 41 місце зі 162 із значенням індексу SDG 72,8. Для співставлення, Білорусь випередила Україну на 18 позицій та посіла 23 місце зі значенням індексу SDG 23,4, Угорщина посіла 25 місце зі значенням індексу SDG 76,9, Польща посіла 29 
місце з індексом SDG 75,9, Молдова - 37 місце 3 показником 74,4. У той же час, Україна випереджає Туреччину на 38 позицій, яка посіла 79 місце зі значення індексу SDG 68,5. Для наочного представлення приведено в табл. 1 країни, які увійшли в ТОП-10 країн за загальним індексом досягнення цілей сталого розвитку та представили позиції країн, які обрали для дослідження відносно досягнень України в табл. 2.

Там, де більше значення загального Індексу SDG - бали за ціллю можна інтерпретувати як відсоток досягнення. Різниця між 100 та балами країн - це «відстань» у відсотках, який потрібно досягти. Важливо, що для всіх країн використовується однаковий набір показників для оцінювання досягнення кожної окремої цілі, щоб отримати порівнювані бали та відповідний представлений рейтинг. Слід зазначити, що різниця у рейтингах може бути пов'язана $з$ невеликою відмінністю в сукупній оцінці. Відмінності двох-трьох місць між країнами не можна сприймати як "значну", тоді як відмінності в 10 позицій можуть показати велику різницю.

Таблиця 1 - Топ-10 країн за показником індексу

SDG 2019 p.

\begin{tabular}{|c|c|c|}
\hline Місце & Країна & $\begin{array}{c}\text { Значення } \\
\text { індексу } \\
\text { SDG }\end{array}$ \\
\hline 1 & Данія & 85,2 \\
\hline 2 & Швеція & 85,0 \\
\hline 3 & Фінляндія & 82,8 \\
\hline 4 & Франція & 81,5 \\
\hline 5 & Австрія & 81,1 \\
\hline 6 & Німеччина & 81,1 \\
\hline 7 & Чеська & 80,7 \\
\hline 8 & Республіка & \\
\hline 9 & Норвегія & 80,7 \\
\hline 10 & Нідерланди & 80,4 \\
\hline & Естонія & 80,2 \\
\hline
\end{tabular}

Таблиця 2 - Рейтинг досліджуваних країн за показником індексу SDG 2019 p.

\begin{tabular}{|c|c|c|}
\hline Мiсце & Країна & $\begin{array}{c}\text { Значення } \\
\text { індексу } \\
\text { SDG }\end{array}$ \\
\hline 4 & Франція & 81,5 \\
\hline 6 & Німеччина & 81,1 \\
\hline 10 & Естонія & 80,2 \\
\hline 13 & Сполучене & 79,4 \\
\hline 20 & Королівство & 77,9 \\
\hline 23 & Білорусь & 77,4 \\
\hline 24 & Латвія & 77,1 \\
\hline 25 & Угорщина & 76,9 \\
\hline 26 & Португалія & 76,4 \\
\hline 30 & Польща & 75,9 \\
\hline 26 & Італія & 75,8 \\
\hline 41 & Україна & 72,8 \\
\hline 79 & Туреччина & 68,5 \\
\hline \multicolumn{3}{|c|}{} \\
\hline
\end{tabular}

Переходячи до оцінювання змінних значень (індикаторів) за окремими цілями нашого дослідження, а саме $8,9,12,17$, то, у першу чергу, для мети аналізу досліджено методологію, запропоновану у вищезазначених звітах 
«Sustainable Development Report» для співставлення показників країн за різними цілями 3 метою визначення прогресу та прогалин. Звіт 2019 р. включає загальну кількість: 114 показників із 85 глобальних індикаторів та 29 індикаторів додано спеціально для країн ОЕСР, включаючи низку нових показників для заповнення прогалин даних. Використана відповідна методика вибору, нормалізації показників, агрегування і генерування показників щодо тенденцій, про що зазначено в самому звіті.

Отже, відповідно до досліджуваного звіту, Україну та досліджувані країни порівнювали за конкретними показниками, а саме: 1) Індикатори за ЦСР 8: темп зростання ВВП, поширеність сучасного рабства, Дорослі (15 років і старше) 3 рахунком у банку чи іншій фінансовій установі або у постачальника послуг 3 мобільного банкінгу; рівень безробіття; смертельні нещасні випадки на виробництві; рівень зайнятості населення; молодь, яка не займається працевлаштуванням, освітою чи навчанням; 2) Індикатори за ЦСР 9: населення, яке використовує Інтернет; передплати на мобільні широкосмугові послуги; Індекс ефективності логістики; рейтинг університетів вищої освіти Times; кількість статей в науково-технічних журналах; витрати на дослідження і розробки; науково-дослідні роботи; кількість тріадних патентних сімейств; розрив у доступі до Інтернету за доходом; жінки в науці та техніці; 3) Індикатори за ЦСР 12: тверді побутові відходи; електронні відходи; виробничі викиди $\mathrm{SO}_{2}$; викиди $\mathrm{SO}_{2}$ пов'язані з імпортом товарів; викиди $\mathrm{CO}_{2}$ та ін. 4) Індикатори за ЦСР 17: державні витрати на охорону та освіту; державні доходи за виключенням грантів та ін.

Відповідно, для того, щоб аналізувати країни між собою, потрібно, щоб для всіх країн використовувався однаковий набір показників для оцінювання досягнення кожної окремої цілі, щоб отримати порівнювані бали та відповідний представлений рейтинг. Тому для України важливо узгодити той набір показників, який подається у відкритий доступ, а саме коректність i співставність індикаторів, відповідно до яких проводиться дослідження. Також відзначимо, що в Україні проводиться моніторинг досягнення цілей відповідно до визначених національних показників.

Загальний показник індексу досягнення цілей сталого розвитку може суттєво відрізнятися від показника країни за конкретно обраною ціллю. Саме тому, нами було зроблено перерахунок балів відповідно до цілей 8, 9, 12, 17 та сформовано рейтинг країн саме в межах цілей $8,9,12,17$. При цьому, було визначено загальний показник за всіма чотирма цілями, та окремо за кожною. Так, Проаналізувавши отриманий рейтинг за всіма країнами за визначеними ЦСР 
можна зазначити причини значних змін позицій країн у рейтингах порівняно 3 рейтингом по усім 17 ЦСР.

Зокрема, Україна при загальному показнику ЦСР займає 41 сходинку глобального рейтингу, а по ЦСР 8, 9, 12, 17 - на 73-му місці. Рейтинг, складений на основі показників по ЦСР 8, теж суттєво відрізняється від глобального. Так, Україна знаходиться на 111 місці та має потенціал для покращення позиції у даному рейтингу. За станом досягнення ЦСР 9 Україна на 96 місці. ЦСР 12 має особливий рейтинг, оскільки у ньому є залежність від нерівності, оскільки топ-20 займають малорозвинені країни. Населення цих країн має низький рівень споживання, що пов'язано 3 малим фінансовим доходом громадян, їх купівельною спроможністю та мало розвиненою інфраструктурою та промисловістю. Тому, відповідно, у цих країнах екологічна ситуація у допустимих межах. Україна в даному рейтингу посіла 91 місце. За станом досягнення ЦСР 17 Україна займає 29-е місце. Дані результати нашого дослідження було опубліковано у Першому Добровільному національному огляді щодо Цілей сталого розвитку в Україні [6].

Для представлення результатів за обраними країнами сформували табл. 3. У стовбцю 1 сформовано рейтинг за сукупною оцінкою (Global Index Score) саме серед досліджуваних 13-ти країн. У стовбцях 2 та 3 зазначені відповідні місця цих країн серед досліджуваних 13-ти країн після перерахунку індексу для чотирьох досліджуваних цілей, та перераховані бали (значення) індексу SDG по чотирьом цілям для цих країн. Далі, за кожною 3 досліджуваних цілей та досліджуваних країн (у порядку поданому в стовбці 1) подали оцінки та місця. У стовбцях 6, 9, 12 та 15 перерахували рейтинг саме для 13-ти досліджуваних країн, враховуючи їх бали та місця у рейтингу країн за окремими цілями. Пунктирними лініями показали зміну рейтингу (місць) країн залежно від оцінки досягнення всіх цілей та окремих цілей. Також, це дозволило нам візуально побачити, які країни серед досліджених більш успішні в досягненні окремих цілей, і враховуючи це, доцільно дослідити саме їх заходи та кейси для досягнення окремих цілей. Наприклад, більший прогрес в досягненні Цілі 8 серед досліджених країн спостерігається в Естонії, Польщі, Німеччині, Канаді. За Ціллю 9 важливо врахувати рейтинг Сполученого Королівства, Німеччини, Канади, Франції, а серед країн-сусідів - Польщі, Угорщини, Туреччини, Білорусі. Враховуючи прогрес країн по Цілі 12, то доцільно враховувати досвід Білорусі, по 17 Цілі - досвід Німеччини. Оскільки за 9 та 12 Цілями Україна займає друге місце серед досліджуваних країн, то доцільно розглянути ще й інші країни, які зайняли вищі місця. 
Таблиця 3 - Зміна рейтингів досліджуваних 13-ти країн в залежності від значень індексів SDG за окремими цілями, 2019 р.

\begin{tabular}{|c|c|c|c|c|c|c|c|c|c|c|c|c|c|c|}
\hline \multicolumn{3}{|c|}{ ЗАГАЛЬНИЙ РЕЙТИНГ } & \multicolumn{3}{|c|}{ РЕЙТИНГ ЗА ЦІЛЬ 8} & \multicolumn{3}{|c|}{ РЕЙТИНГ ЗА ЦІЛЬ 9} & \multicolumn{3}{|c|}{ РЕЙТИНГ ЗА ЦЛЬ 12} & \multicolumn{3}{|c|}{ РЕЙТИНГ ЗА ЦІЛЛЮ 17} \\
\hline 1 & 2 & 3 & 4 & 5 & 6 & 7 & 8 & 9 & 10 & 11 & 12 & 13 & 14 & 15 \\
\hline 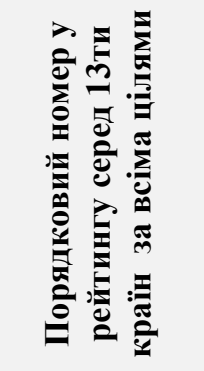 & 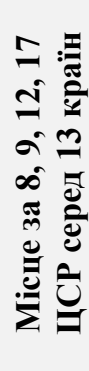 & 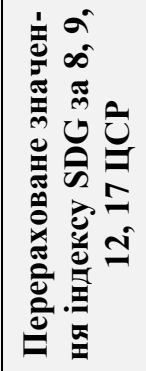 & 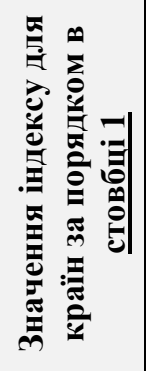 & 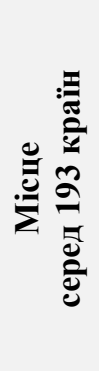 & 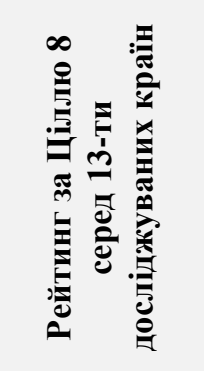 & 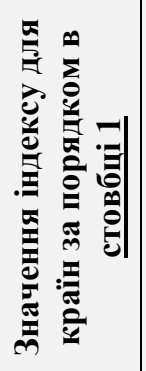 & 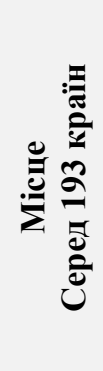 & 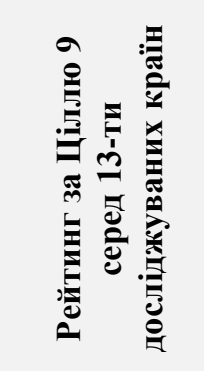 & 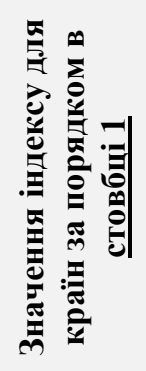 & 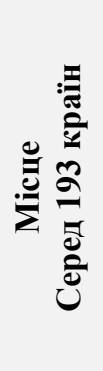 & 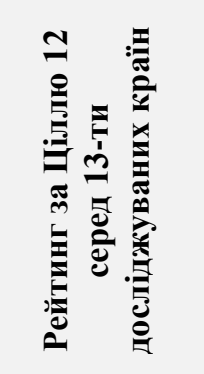 & 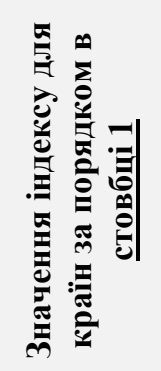 & 童 & 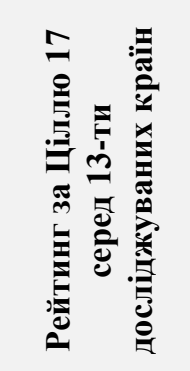 \\
\hline $\begin{array}{c}\text { Франція } \\
\text { (1) }\end{array}$ & 2 & 70,1 & 78,1 & 47 & $\begin{array}{c}\text { Естонія } \\
- \text { (1) }\end{array}$ & 73,6 & 20 & $\begin{array}{l}\text { CK } \\
\text { (i) }\end{array}$ & 53,4 & 137 & $\begin{array}{c}\text { Білорусь } \\
\text { (1) }\end{array}$ & 75,1 & 36 & $\begin{array}{c}\text { Німеччина } \\
\text { (1) }\end{array}$ \\
\hline $\begin{array}{l}\text { Німеччина } \\
\text { (2) }\end{array}$ & 1 & 73,8 & $.84,4^{--}$ & 14 & $\begin{array}{c}\text { Польша' } \\
\text { (2) }\end{array}$ & 80,4 & 11 & $\begin{array}{l}\text { Німеччйна } \\
\text { (2) }\end{array}$ & 47,4 & 146 & $\begin{array}{c}\text { Україна } \\
2(2)\end{array}$ & $\therefore \quad 83,1$ & 15 & $\begin{array}{c}\text { Україна } \\
(2)\end{array}$ \\
\hline $\begin{array}{c}\text { Естонія } \\
\text { (3) }\end{array}$ & $7^{--1}$ & 65,1 & 84,8 & $11 \cdots$ & $\begin{array}{c}\text { Німеччина } \\
\text { (3) }\end{array}$ & $61 ; 5$ & 27 & $\begin{array}{r}\text { Канада } \\
-(3) \\
\end{array}$ & 58,7 & 130 & $\begin{array}{l}\text { Туреччина } \\
\text { (3) }\end{array}$ & 55,5 & -119 & $\begin{array}{c}\text { Франція } \\
\text { (3) }\end{array}$ \\
\hline $\begin{array}{l}\text { CK } \\
\text { (4) } \cdots \cdots\end{array}$ & 9 & 64 & 82,9 & 22 & Канада & -81.4 & $\because 10$ & $\begin{array}{c}\text { Франція } \\
\text { (4) }\end{array}$ & 42, & 151 & $\begin{array}{l}\text { Польща } \\
\text { (4) }\end{array}$ & 48,9 & 141 & $\begin{array}{c}\text { Білорусь } \\
\text { (4) }\end{array}$ \\
\hline $\begin{array}{c}\text { Канада } \\
(5)\end{array}$ & 3 & 68,5 & $84 i$ & 14 & $\begin{array}{l}\text { Латвія } \\
\text { (5) }\end{array}$ & 74,4 & 18 & \begin{tabular}{c}
\multicolumn{2}{c}{ Італія } \\
$\because \quad(5)$ \\
\end{tabular} & 501 & 142 & $\begin{array}{c}\text { Угорщина } \\
\text { (5) }\end{array}$ & 65,4 & 68 & $\begin{array}{c}\text { Tуреччина } \\
\text { (5) } \\
\end{array}$ \\
\hline $\begin{array}{c}\text { Білорусь } \\
\text { (6) }\end{array}$ & 4 & 68,4 & $\cdot 77,4$ & 52 & $\begin{array}{c}\mathbf{C K} \\
(6)\end{array}$ & 39,3 & $60 \backslash$ & $\begin{array}{r}\text { Есттонія } \\
(\mathbf{6})^{-\cdots}\end{array}$ & & 2 & $\begin{array}{c}\text { Латвія } \\
(6)\end{array}$ & 74,2 & 41 & $\begin{array}{c}\text { Канада } \\
\text { (6) }\end{array}$ \\
\hline $\begin{array}{c}\text { Латвія } \\
\text { (7) }\end{array}$ & 13 & 62,7 & 83,3 & 18 & $\begin{array}{c}\text { Португалія } \\
\text { (7) }\end{array}$ & 49,3 & 40 & $\begin{array}{r}\text { Португалія } \\
\text { (7) . }\end{array}$ & & 120 & Естонія & 50 & & $\begin{array}{l}\text { Італія } \\
\text { (7) }\end{array}$ \\
\hline $\begin{array}{c}\text { Угорщина } \\
(8)\end{array}$ & 10 . & 63,6 & 82,1 & 27 & $\begin{array}{c}\text { Угорщина } \\
(8)\end{array}$ & 49,6 & 39 & $\begin{array}{c}\text { Польща } \\
\text { (8) }\end{array}$ & & & $\begin{array}{c}\text { Португалія } \\
\text { (8) }\end{array}$ & & & $\begin{array}{c}\text { Португалія } \\
\text { (8) }\end{array}$ \\
\hline $\begin{array}{c}\text { Португалія } \\
(9)\end{array}$ & $i_{11}$ & 63,0 & 82,3 & 25 & $\begin{array}{c}\text { Італія } \\
(9)\end{array}$ & 56,1 & 33 & $\begin{array}{c}\text { Угорщина } \\
(9) \\
\end{array}$ & & 135 & $\begin{array}{c}\text { Франція } \\
(9)\end{array}$ & ${ }^{\prime}$ & 105 & $\begin{array}{c}\text { Естонія } \\
(\tilde{9})\end{array}$ \\
\hline $\begin{array}{c}\text { Польща } \\
\text { (10) }\end{array}$ & 5 & 66,6 & 84,4 & 13 & $\begin{array}{c}\text { Франція } \\
(10)\end{array}$ & 54,9 & 34 & $\begin{array}{c}\text { Латвія } \\
\text { (10) }\end{array}$ & & 109 & $\begin{array}{l}\text { Уталія } \\
\text { (10) }\end{array}$ & 53,4 & 126 & $\begin{array}{c}\text { Польщща } \\
\text { (10) }\end{array}$ \\
\hline $\begin{array}{c}\text { Італія } \\
\text { (11) }\end{array}$ & 8 & 64,3 & 78,7 & 42 & $\begin{array}{l}\text { Білорорусь } \\
\text { (11) }\end{array}$ & 63,8 & 24 & $\begin{array}{c}\text { Туреччина } \\
\text { (11) }\end{array}$ & 51,7 & 139 & $\begin{array}{c}\text { Канада } \\
\text { (11) }\end{array}$ & 63,1 & 81 & $\begin{array}{c}\text { Угорщина } \\
\text { (11) }\end{array}$ \\
\hline $\begin{array}{c}\text { Україна } \\
\text { (12) } \\
\end{array}$ & 12 & 62,9 & 68,4 & 111 & $\begin{array}{c}\text { Туреччина } \\
\text { (12) }\end{array}$ & 25,2 & 96 & $\begin{array}{c}\text { Білорусь } \\
\text { (12) }\end{array}$ & 80,4 & 91 & $\begin{array}{l}\text { Німеччина } \\
\quad \text { (12) }\end{array}$ & 77,9 & 29 & $\begin{array}{c}\text { Латвія } \\
\text { (12) }\end{array}$ \\
\hline $\begin{array}{c}\text { Туреччина } \\
\text { (13) }\end{array}$ & 6 & 66,2 & 73,8 & 75 & $\begin{array}{c}\text { Україна } \\
\text { (13) } \\
\end{array}$ & 46,5 & 45 & $\begin{array}{c}\text { Україна } \\
\text { (13) }\end{array}$ & 73,8 & 108 & $\begin{array}{l}\text { CK } \\
(\mathbf{1 3}) \\
\end{array}$ & $70 ; 8$ & -50 & $\begin{array}{l}\text { CK } \\
\text { (13) }\end{array}$ \\
\hline
\end{tabular}

Розроблено авторами на основі [2] 
Також, за даними [5] визначили динаміку реального ВВП на душу населення в досліджуваних країн та іiі графічне зображення подали на рис. 1.

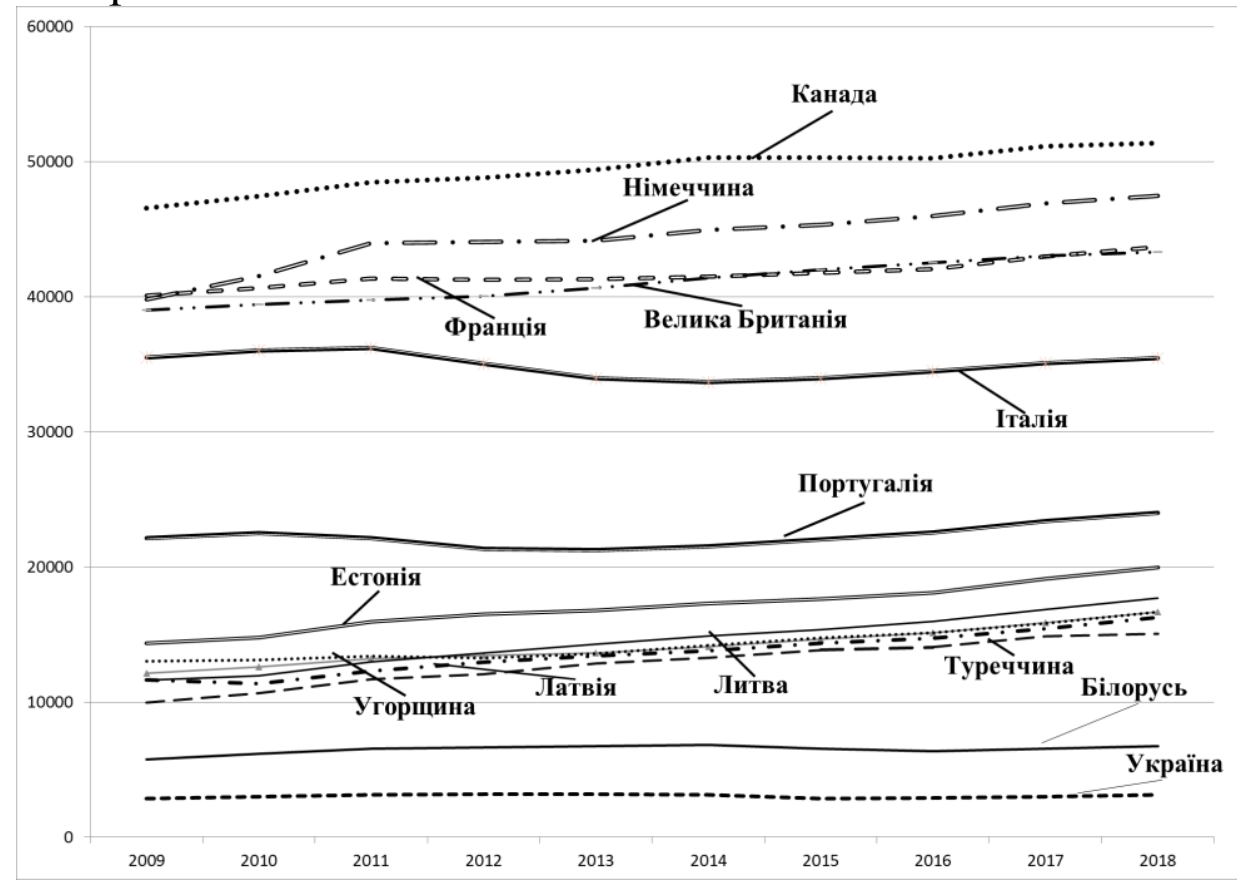

Рисунок 1 - Реальний ВВП на душу населення в досліджуваних країнах

з 2009 по 2018 рр. ВВП на душу населення), постійний долар США

$$
\begin{aligned}
& 2010 \text { року } \\
& \text { Джерело: } 7
\end{aligned}
$$

Ще одним важливим загальним глобальним показником, який відображає досягнення по Цілі 9 та частково Цілі 8 є глобальний інноваційний індекс (ГІІ) - це оцінювання інноваційної потенціалу країни, яка визначає місце країн за інноваційним розвитком у світі [3]. Також ГІІ надає змогу визначити сильні та слабкі сторони інноваційної системи та політики країни. Для того, щоб розрахувати глобальний інноваційний індекс доцільно знайти половину суми індексів входу та виходу, де індекс входу - це інноваційний потенціал країни, а виходу це результати наукової та інноваційної діяльності країни.

За цим показником у рейтингу до топ-5 входять: Швейцарія, Швеція, США, Нідерланди та Великобританія. Розглянемо значення ГІІ у ретроспективі: у 2015 році для Швейцарії він складав 68,30 балів, а у 2019 відбулося зниження на 1,6\%- до 67,24. У Швеції з 2015 року показник зріс на 2,0\% та у 2019 році склав 63,65 балів; у США зріс на 2,6\% і склав 61,73 бали у 2019 році; у Нідерландах знизився на 0,22\% та склав 2019 році 61,44 бали; індекс Великобританії знизився на 1,8 \% та склав у 2019 році 61,30 [3].

Розглянемо також зміни глобального інноваційного індексу для країн-сусідів України. У 2019 році Білорусь посіла 72 місце, Молдова 58 місце, Польща - 37 місце, РФ - 41 місце, Словаччина та Угорщина 
посідають, відповідно, 37 та 33 місця. 32015 року по 2019 рік індекс Білорусії впав на 19,0\% та у 2019 році складав 32,07 бали; у Молдові знизився на 14,1\% та у 2019 році складав 35,52; індекс Польщі зріс на $2,8 \%$ та у 2019 році склав 41,31 ; у РФ знизився на $4,5 \%$ та у 2019 станови 37,62; у Словаччині знизився на $2,2 \%$ та у 2019 р. становив 42,05 та для Угорщини на 3,4\% зріс й у 2019 році дорівнює 44,51. Враховуючі ці та раніше зазначені дані, доцільно в 9 та 17 цілях врахувати досвід Польщі та Угорщини.

Україна в 2019 році посіла у даному рейтингу 47 місце з індексом 37,47. 32015 по 2019 рр. показник зріс на 2,7\%. Порівнюючи Україну та іiі сусідів найбільше зростання глобального інноваційного індексу відбулося в Угорщині та найбільше зниження відбулося у Білорусії [3].

Одним 3 показників, який можна віднести до індикаторів за ЦСР 12 є індекс екологічної ефективності (IEE) - комбінований показник стану екології й ефективності управління природними ресурсами. IEE розраховується 32006 р. і використовується для розрахунку Індексу розвитку людського потенціалу в рамках Програми розвитку Організації Об'єднаних Націй. Результати дослідження публікуються один раз у два роки [4]. У 2018 р. було розроблено рейтинг для 180 країн. Відповідно до нього, Україна посіла 109 місце, поруч 3 Туреччиною - 108 місце, що нижче ніж інші досліджені країни. Наприклад, Франція посіла 2 місце, Німеччина - 13 місце, Канада - 25 місце, Білорусь - 44 місце, Польща - 50 місце. Все це свідчить про те, що треба запроваджувати механізми підвищення рівня екологічні ефективності в Україні та аналізувати зарубіжний досвід досліджених країн.

Висновки. Отже, результати дослідження надають змогу визначити ті країни, досвід яких доцільно врахувати при досягненні конкретної цілі сталого розвитку. Враховуючи отримані результаті, а саме, визначені положення в рейтингу в сукупності за чотирма цілями сталого розвитку та аналіз по окремим цілям серед досліджуваних країн, доцільно в подальшому проаналізувати деякі завдання та заходи в межах обраних цілей в країнах, які досягли прогресу за досліджуваними цілями. Варто звернути увагу на такі країни як Естонія, Польша Німеччина, Канада у зв'язку з успіхами в досягненні 8 ЦСР, врахувати досвід Сполученого Королівства, Німеччини, Канади, Франції, Португалії, Польші у досягненні ЦСР 9, дослідити заходи Білорусі з досягнення ЦСР 12 і Німеччини з досягнення ЦСР 17. Важливо у процесі дослідження проаналізувати як окремі нормативноправові документи стосовно сталого розвитку окремих країн (соціально-економічні програми, національні стратегії тощо), так i визначені окремі заходи конкретних країн на шляху до досягнення 
певних цілей сталого розвитку. А саме, дослідити заходи профільних міністерств країн, які відповідають за окремі питання розвитку в межах їх компетенцій.

Науковою новизною роботи є методичний підхід до застосування інструментарію щодо оцінювання та співставлення результатів досягнення конкретних цілей сталого розвитку конкретної країни в напрямі економічного зростання, який надає змогу оцінити саме цілі, що стосується економіки та визначити країни для наслідування 3 метою подальшого аналізу їх заходів та імплементації відповідних проектних рішень.

\section{Лiтература:}

1. Цілі сталого розвитку в Україні. Міністерство розвитку економіки. торгівлі та сільського господарства України. URL: http://un.org.ua/images/SDGs_ NationalReportUA_Web_1.pdf (дата звернення: 10.12.2019).

2. Звіти зі сталого розвитку "Sustainable Development Report" (2020), https://www.sdgindex.org/reports/ (дата звернення: 15.02.2020)

3. Глобальний індекс інновацій. URL: https://www.globalinnovationindex.org/gii2019-report (дата звернення: 30.03.2020)

4. Індекс екологічної ефективності. URL: https://epi.yale.edu/ (дата звернення: 30.03.2020)

5. Міжнародний валютний фонд. URL: https://www.imf.org/external/index.htm (дата звернення: 30.03.2020)

6. Цілі сталого розвитку: Україна. Добровільний національний огляд. URL https://sustainabledevelopment.un.org/content/documents/26294VNR_2020_Ukraine_ Report.pdf (дата звернення: 10.06.2020)

7. Трофименко О. О, Дорошкевич Д. В., Джадан I. М. Використання засад глобальних цілей сталого розвитку для забезпечення розвитку промисловості України. Підприємництво та інновації № 11-1(2020). С. 118-125.

\section{References:}

1. Ministry for Development of Economy, Trade and Agriculture of Ukraine (2019) Sustainable Development Goals: Ukraine, Available at: http://un.org.ua/images/SDGs_NationalReportUA_Web_1.pdf (Accessed: 10 December 2019).

2. Sustainable Development Report (2020), available at: https://www.sdgindex.org/reports/sustainable-development-report-2019/(Accessed 15 April 2020).

3. Global Innovation (2020), available at: https://www.globalinnovationindex.org/gii-2019-report (Accessed 30 March 2020).

4

Environmental Performance Index (2020), available at: https://epi.yale.edu/ (Accessed 30 March 2020).

5. The International Monetary Fund (2020), available at: https://www.imf.org/external/index.htm (Accessed 30 March 2020).

6. Sustainable Development Goals: Ukraine. Voluntary National Review (2020), available 
https://sustainabledevelopment.un.org/content/documents/26294VNR_2020_Ukraine_ Report.pdf (Accessed 10 June 2020).

7. Trofymenko O., Doroshkevych, D. and Dzhadan I, 'Using the principles of global goals of sustainable development to ensure the development of Ukrainian industry' (2020) 11-1 Entrepreneurship and Innovation 118. 